\title{
Psychological Contract as a Mediator of the Leadership- Turnover Intentions Relationship
}

\author{
Bas Kodden \\ Nyenrode Business University \\ Jochem Roelofs \\ Nyenrode Business University
}

We developed and tested a model examining the influence of leadership styles on the psychological contract of different generations of professionals and subsequently their turnover intentions. The study proposed that there is a relationship between leadership styles and psychological contract breach and subsequently the turnover intentions of legal professionals - lawyers, tax advisors, and (candidate) civil law notaries - working in professional service firms. Because of the strategic importance of human capital in a professional service firm, it is important for the continuity of the organization that they will retain their legal professionals and inspire young associates to become future shareholders.

\section{INTRODUCTION}

While numerous research articles have been published examining the antecedents of turnover, few have examined the consequences of turnover (Holtom, Mitchell, Lee, \& Eberly, 2008). This research reveals that high levels of employer turnover can have serious negative effects on legal service organizations. Specifically, there is support for the argument that voluntary turnover disrupts normal operations of the firm (Staw, 1980) and engenders the loss of firm-specific human and social capital (Dess \& Shaw, 2001; Morrow \& McElroy, 2007), thereby strongly decreasing the chances of continuation of the legal service firm. We proposed that there is a relationship between leadership styles, psychological contract breach and turnover intentions. While several studies have examined the relationship between turnover and leadership, relatively few have theorized that and measured the mediation of psychological contract breach and even fewer have attempted to test this mediation effect within professional legal service firms. There is a critical need to examine the "the black box" or the theoretical intermediaries of this effect. We address this gap by proposing and testing a model where psychological contract breach mediates the relationship between leadership styles and turnover intentions. Five hypotheses were formulated to investigate each relationship between the constructs in the model. The model was designed in such a way that, if an effect of perceived leadership style on turnover intentions was measured, the mediating psychological contract was the possible explanation of this effect. Human capital is of strategic importance to a law firm, and "retaining human capital is very important in the ever-increasing competition to employ the most valuable employees in the marketplace" (Carmeli \& Weisberg, 2006, 
p.191). We believe it is critical to explore the role that leadership styles and psychological contract breach play in influencing turnover intentions.

\section{THEORY AND HYPOTESES}

\section{Theorized Mechanism for the Turnover- Performance Relationship}

Several theories predict the negative influence of turnover levels on organizational performance. According to operational disruption theory (Hausknecht, Trevor, \& Howard, 2009), employee turnover affect "the ability of others to produce because of the interdependence of work roles,", disrupting the normal operations of the unit and diverting unit-resources (i.e. people, time, and money), toward dealing with this disruption. The human capital theory (Becker, 1964) predicts that turnover leaders to the depletion of firm specific human capital and therefore to a decline in firm performance (Shaw et al., 2005). Because firm-specific human capital includes employees' knowledge of "specific product features and service agreement" employee turnover can result into a loss of customer-related knowledge and lead to lowered levels of customer service (Liao, Toya, Lepak, \& Hong, 2009). Other researcher focused on social capital or the connection between members of an organization view turnover as leading to the dissolution of key relationships between organizational members (Adler \& Kwon, 2002; Leana \& VanBuren, 1999). Regards of turnover type, loss of highly trained professionals can lead to lowered levels of efficiency (Shaw et al, 2005b) and lowered level of customer satisfaction (Morrow \& McElroy, 2007). In the context of relationship-based service organizations such as legal service firms, other researchers believe that high rates of turnover of full-time, permanent staff member can disrupt the ability of these firms to form effective service relations with their customers and, thereafter, financial performance (Subramony \& Holtom (2011).

\section{Leadership Style and Turnover Intention}

Because of the strategic importance of human capital, turnover and the practices of human resource management and leadership to retain, develop and recruit employees are acknowledged by legal service firms (Carmeli \& Weisberg, 2006). Leadership behavior is addressed as a "pull-to-stay" force when it comes to turnover intentions (Waldman, Carter, \& Hom, 2015). To investigate what type of leadership is perceived by the junior associates of the firm, and which leadership style has the least negative influence on turnover intentions, this study investigates the effect of two relatively opposite types of leadership styles, directive leadership and empowering leadership. Since most of the junior associates of the firm have little job autonomy and that they learn the job by looking over the shoulder of the senior lawyer, expected is that an authoritarian or directive leadership style will be practiced. Especially when there is a strong master-apprentice relationship and when competition is fierce among the junior professionals. To be able to have the best result of this study in terms of differences in perceived leadership style, an opposite leadership style which enables the young professionals to be intellectually stimulated and encouraged about the profession will also be included in this study: empowering leadership.

\section{Leadership Styles and Psychological Contract Breach}

The psychological contract concerns the beliefs of an employee about what an employer owes them, and what they want to reciprocate (De Cuyper, Van der Heijden, \& De Witte, 2011a). Based on Rousseau's (1990) largely accepted definition, the psychological contract can be defined as "the individual's beliefs about mutual obligations, in the context of the relationship between employer and employee" (as cited in Van der Smissen, Schalk, \& Freese, 2013). This definition emphasizes that the psychological contract is about individual interpretations and perceptions about promises made in the relationship between employee and employer. According to Van der Smissen et al. (2013), psychological contracts are also influenced by social contracts, which are general beliefs in society about contracts that influence how promises are interpreted by individuals.

Leadership styles that support the firm's HR strategy enable making psychological contracts that benefit both the firm and its professionals. For good results, the leadership style practiced also needs to be 
congruent with HR strategy and practices (McDermott, Conway, Rousseau, \& Flood, 2013). Van der Smissen et al. (2013) points out that it is important to understand how, and to what degree, the psychological contract is affected by different factors.

Although leaders are expected to inspire and motivate subordinates instead of purely controlling and directing them (Hakimi, van Knippenberg, \& Giessner, 2010), in contemporary law firms this is probably not the practiced leadership style as competition, expertise and experience is a key driver for success within the legal service firm.

To identify a leadership definition that best fits this research, the Leadership Circumplex (LC) of Redeker, de Vries, Rouckhout, Vermeren, and de Fruyt (2014) was used. With the LC the researchers hypothesized that leadership can be summarized in two dimensions; agency and communion. According to Redeker et al. (2014), people with a directive leadership style can be described as: "Persons with a directive leadership style tend to try to reach success competitively, tend to actively monitor and correct subordinates, and to behave strictly towards subordinates." Exemplar items are "supervises the work of the staff members carefully," "has severe judgments about staff members," and "is competitive." Given that there is a competitive environment between professionals working for a legal service firm, and that the profession is learned by the hand of the master, this study expects that directive leadership behavior is practiced in law firms. It is expected that this style of leadership has a push-to-leave effect on employees working for the firm. Consequently, the following hypothesis is suggested:

Hypothesis 1: The directive style of leadership will be positively related to psychological contract breach.

To contrast this positive effect of directive style of leadership on psychological contract breach we used the empowering style of leadership. When an employee has autonomy and can direct their own actions to complete tasks and solve problems, they become engaged (Sawa \& Swift, 2013). Employee empowerment refers to high individual motivation, by the delegation of responsibility and authority to the lowest organizational level where a competent decision can be made (Thomas \& Velthouse, 1990); in other words, a leader that shares power with subordinates, empowers those employees to take responsibility for tasks to be done. Most high- performing professionals desire high levels of responsibility as it is part of their psychological makeup (Sawa \& Swift, 2013). Empowering leadership focuses on the development of follower self-management or self-leadership skills (Pearce et al., 2003). Therefore, the following hypothesis is suggested:

Hypothesis 2: The empowering style of leadership will be negatively related to psychological contract breach.

\section{Psychological Contract Breach and Turnover Intentions}

According to Clinton and Guest (2014), voluntary turnover is often presented as an outcome of a breach of the psychological contract between employee and employer. This "psychological contract breach" damages the connection between the employee and the employing firm and causes the employee to question benefits and obligations associated with remaining in the relationship (Clinton \& Guest, 2014). Changes in the relationship between employer and employee, for example, changing teams, tasks or work pace, has an impact on organizations, jobs, and contracts. This results in declining mutual loyalty between employer and employee (Van der Smissen, et al., 2013).

According to Van der Smissen et al. (2013), researchers have searched for empirical evidence that contemporary psychological contracts differ from old psychological contracts, but due to scarce research on this topic they found mixed results. However, additional factor added to the old psychological contractual elements of job security, continuity, loyalty and fairness, is the balance between work and private life. According to Waldman et al. (2015), the psychology of employees leaving the company differs from those who stay, and that this has unique variance in turnover intentions beyond job alternatives or job satisfaction. 


\section{Hypothesis 3: Psychological contract breach will be positively related to turnover intentions}

Based on the above rationale, we propose that the detrimental effect of the directive style and the beneficial effect of the empowering style of leadership on turnover intention will be fully mediated by psychological contract breach.

Hypothesis 4: The negative relationship between the directive style of leadership and turnover intentions will be fully mediated by psychological contract breach.

Hypothesis 5: The postive relationship between the empowering style of leadership and turnover intentions will be fully mediated by psychological contract breach.

\section{METHOD}

\section{Sample and Procedure}

Our sample consisted of 61 representatives of legal service firms in the Netherlands. The population of the 61 respondents represented 36 women (59\%) and 25 men (41\%). Of the respondents, 55.7\% (34) were younger than 30 years of age, 42.6\% (26) were between 30 and 49 years of age, and 1 respondent $(1.6 \%)$ was between $50-69$ years of age. Approximately $59 \%$ of the population worked at a law firm that employs between 100 and 250 legal professionals, almost 30\% worked at law firms with less lawyers and nearly $12 \%$ worked at law firms with more than 250 lawyers and/or (candidate) civil law notaries in the Netherlands. The area of expertise or practice area of the population was widely spread. The largest groups were experts in Litigation and Dispute Resolution (15\%), Employment, Benefits and Labor (13\%) and Corporate Mergers and Acquisitions (12\%).

\section{Measures}

Directive Leadership Style

12 items from the Circumplex Leadership Scan (CLS) of Redeker et al. (2014) were used to measure directive leadership. These items were measured using a 5-point Likert- scale, ranging from "Never (1)" to "Always (5)." Example items are "My manager requires detailed reporting of the work done" and "My manager claims blind confidence in his / her decisions."

\section{Empowering Leadership Style}

Empowering Leadership was measured with 12 items of Ahearne, Mathieu, and Rapp (2005). The items were measured on a 5-point Likert-scale, but with a slightly different textual meaning ranging from "Strongly disagree" (1) to "Strongly agree" (5). The items can be categorized into four contextual groups. For example, three items belong to "Fostering participation in decision making." These cohesive groups were not expressed in the survey. An example item to measure Empowering Leadership is "My manager often consults me on strategic decisions."

\section{Psychological Contract Breach}

To measure Psychological Contract Breach, 5 items of Robinson and Morrison (2000) were included in the questionnaire. These items are rated on a 5-point Likert-scale: "Strongly disagree" (1) to "Strongly agree" (5). An example of a (reversed) item is "Almost all the promises made by my employer during recruitment have been kept so far." The internal consistency of this scale $(A l p h a=.84)$ was found to be high.

\section{Turnover Intentions}

The employee's turnover intention was assessed by a three-item measure, based on the theory of Jones (2010). It was measured on a 7-point Likert-scale ranging from "Strongly disagree" to "Strongly 
agree" and included two reverse coded questions, for example "The chances of me quitting my job in the next year are low." The internal consistency of this scale (Alpha $=.87)$ was also found to be high.

\section{Control Variables}

Based on previous evidence indicating that age can affect the relationship between leadership styleturnover intentions and psychological contract breach (Bontekoning, 2017), we controlled for generation groups of the representatives of the legal service firms. Changing expectations by employees towards their relationship and psychological contract with their employer can be explained by generational differences. According to Lub, Blomme, and Bal (2011), literature on generational differences regarding psychological contracts is inconclusive. Scholars have found that generation Y differs in how they judge work values; their work life balance, work training and personal development are more important, while at the same time they like teamwork and a pleasant work environment (Van der Smissen et al., 2013). This shift in the employees' attitude, values and expectations regarding leadership style, motivation, working hours, opportunities for development, autonomy, and meaningful work experiences can also be the starting point of a change in the psychological contract. To contribute empirical evidence that younger generations have different values in their psychological contract, and that this could lead to different outcomes when it comes to turnover intentions, this research focusses on a multi group analysis of different generations. A generation is then an identifiable group of people who are all born in a limited time span of consecutive years, and share birth years, age, and live in a similar social location experiencing similar social events (Glass, 2007; Lub, Nije Bijvank, Bal, Blomme, \& Schalk, 2012; Macky, Gardner, \& Forsyth, 2008). Internationally, academics and practitioners generally distinguish the following four generations: Traditionalists (born before 1945), Baby Boomers (born between 1945 and 1965), Generation X (born between 1965 and 1985) and Generation Y (born between 1985 and 2000).

This research will use the more internationally recognized terms as starting point, as most literature speaks of Generation $\mathrm{X}$ and Generation $\mathrm{Y}$ as the youngest two generations currently active in organizations. The upcoming generation (people born after 2000), in this study referred to as Generation $Z$, will enter the job market in the next 5 to 10 years, and can therefore not be included in this study.

\section{Data Analysis}

Due to the textual modifications to the validated items in the survey, an exploratory factor analysis and reliability analysis had to be conducted. An Exploratory Factor Analysis (EFA) determines if a large number of variables can be represented by one or more factors of the constructs. According to Brace, Kemp and Snelgar (2012) the EFA method investigates the pattern of correlations between variables to detect if an underlying structure exists. The results of an EFA indicate the number of factors that can be used to represent the variables, and which variables make up each of the factors in the model. The extraction of the factors was done using the Principal Axis Factoring method. The scree-test based on eigenvalues greater than 1 was used to identify the number of factors to retain for rotation. To establish and interpret more easily which factors correlate, the oblique rotation technique (direct oblimin) was used. This method was chosen because it was expected that the underlying factors correlate based on the theoretical research, and that this technique is generally used in research that focuses on behavior. Items with a factor loading less than .32 were discarded, as were items that cross loaded with a value higher than .32 on more than one factor. The cumulative variance explained by the factors extracted should be $50 \%$ or higher (Costello \& Osborne, 2005). Per factor the Kaiser-Meyer-Olkin (KMO) measure of sampling adequacy was checked. A KMO score that is close to one indicates that the factor analysis should give distinct and reliable results, while a low score (below .50) indicates that the result of the factor extraction is more likely to be unreliable. To assess the reliability and internal consistency, the Cronbach Alpha value was calculated for each factor. The minimum accepted value to determine whether the factor is treated as significant is 0.70 . In addition to the assessment of the Cronbach Alpha, the itemtotal correlation was examined and checked if the value was at least .30. 


\section{RESULTS}

Table 1 displays descriptive statistics, correlations, and coefficient alphas for all factors extracted from the survey data. There are no descriptive statistics and correlations measured between the construct "Directive Leadership" and the other constructs. Hypothesis 1 predicted that a higher perceived directive leadership style would result into the higher levels of perceived psychological breach. Due to the fact that it was unsuccessful to extract one or more factors from the sample regarding the items that measured directive leadership, this hypothesis cannot be tested. The construct of empowering leadership in this research is divided into two dimensions, represented by factor 1 (PCA) and factor 2 (M). Table 1 shows that the first factor, PCA, which was extracted from the items measuring empowering leadership, is positively correlated $(\mathrm{r}=.65, \mathrm{p}<0.01)$ to the second factor of empowering leadership $(\mathrm{M})$. Both factors are significantly related to psychological contract breach, with the negative factors $-.46(\mathrm{p}<0.01)$ and $.55(\mathrm{p}<0.01)$ respectively. Hypothesis 2 stated that when empowering leadership is perceived by professionals working in a legal service firm, there will be a negative correlation with the psychological contract breach.

Moreover, in line with hypothesis 2 (H2), empowering leadership factor 1 (PCA) is also negatively related to turnover intentions $(\mathrm{r}=-.32, \mathrm{p}<0.05)$, as is factor $2(\mathrm{r}=-.43, \mathrm{p}<0.01)$. Hence, from this research there is a strong indication that if there is a high perception of empowering leadership measured, this will lead to lower turnover intentions. Finally, within this study the construct of psychological contract breach is correlated with turnover intentions with a positive factor of $.38(\mathrm{p}<0.01)$.

TABLE 1 DESCRIPTIVE STATISTICS AND INTERCORRELATIONS BETWEEN VARIABLES IN THE STUDY

\begin{tabular}{lllccccc}
\hline & Mean & SD & 1 & 2 & 3 & 4 \\
1. & $\begin{array}{l}\text { Empowering Leadership (Factor 1, } \\
\text { PCA) }\end{array}$ & 3.57 & 0.73 & .88 & & & \\
2. & & & & & & \\
Empowering Leadership (Factor 2, & 3.56 & 0.77 & $.65^{* *}$ & .91 & & \\
M) & & & & & & \\
3. & Psychological Contract Breach & 2.46 & 0.70 & $-.46^{* *}$ & $-.55^{* *}$ & .84 & \\
4. Turnover Intentions & 3.26 & 1.82 & $-.32^{*}$ & $-.43^{* *}$ & $.38^{*}$ & .87 \\
& & & & & $*$ & \\
\hline
\end{tabular}

$* * p .01 ; * p .05 ; \dagger p .10$

As the constructed conceptual model expected a mediating effect of the mediating variable Psychological Contract Breach, a mediation analysis was performed. Mediation analysis was done using Andrew Hayes' PROCESS add-in for SPSS (Hayes, 2014). As the items in the survey used different scales, the Z-score was calculated to be able to compare scores from the different normal distributions. Furthermore, as Hayes' PROCESS uses unstandardized coefficients in its output, for each of the relations the $\beta$ (beta) was calculated with a linear regression report and used to define the significance of the relationship. 
TABLE 2

MEDIATION MODEL

\begin{tabular}{|c|c|c|c|c|c|}
\hline Direct effects & coeff & SE & $\mathbf{t}$ & $\mathbf{p}$ & Model R2 \\
\hline \multicolumn{6}{|c|}{ Psychological Contract Breach as dependent variable } \\
\hline Constant & 4.06 & .40 & 10.02 & .0000 & \\
\hline Empowering Leadership (PCA) & -.45 & .11 & -4.03 & .0002 & .22 \\
\hline Constant & & & & & \\
\hline \multicolumn{6}{|l|}{$\begin{array}{l}\text { Turnover Intention as dependent } \\
\text { variable }\end{array}$} \\
\hline Constant & 3.11 & 1.79 & 1.73 & .08 & \\
\hline Empowering Leadership (PCA) & -.47 & .34 & -1.39 & .17 & \\
\hline Psychological Contract Breach & .75 & .35 & 2.13 & .04 & .17 \\
\hline Indirect effects & effect & Boot SE & Boot & LLCI & BOOT ULCI \\
\hline $\begin{array}{l}\text { Psychological Contract Breach on } \\
\text { Turnover Intentions }\end{array}$ & -.33 & .15 & -.65 & & -.04 \\
\hline $\begin{array}{l}\text { Kappa-squared for indirect effect } \\
\text { Psychological Contract Breach on } \\
\text { Turnover Intentions (k2) }\end{array}$ & $\begin{array}{l}\text { effect } \\
.13\end{array}$ & $\begin{array}{l}\text { Boot SE } \\
.05\end{array}$ & .02 & LLCI & $\begin{array}{l}\text { BOOT ULCI } \\
.20\end{array}$ \\
\hline
\end{tabular}

Table 2: Mediation outcome of Empowering Leadership (PCA) - Psychological Contract Breach - Turnover Intentions. Effect size estimates are unstandardized coefficients except for Kappa- squared.

The results in Table 2 show that the second factor of empowering leadership, which can be grouped under the category "meaningfulness of the work" (M), significantly predicts psychological contract breach $(\mathrm{b}=-.50, \mathrm{t}=-5.07, \mathrm{p}=.00)$, and explains $30 \%(\mathrm{R} 2)$ of the variance in psychological contract breach. The outcome also shows that the relationship is negative; when a higher degree of empowering leadership (M) is perceived, Psychological contract breach declines as hypothesized. However, in contrast to the first extracted factor of empowering leadership (PCA), empowering leadership factor 2 (M) is still a significant predictor on turnover intentions when the construct of psychological contract breach is in the model $(\mathrm{p}=.03)$. Psychological contract breach does not significantly predicts turnover intentions $(\mathrm{p}=$ .16). The indirect effect bootstrap confidence range also shows that the interval crosses zero, which means that there is likely no mediation effect of psychological contract breach as mediator between empowering leadership (M) and turnover intentions.

\section{DISCUSSION}

Legal service firms flourish on the hiring of recently graduated legal talents and retaining experienced lawyers as they are the most important assets of the law firm. Therefore, these legal professional service firms carefully select, educate, form and nurture their junior professionals to become that unique asset that is at the core of the legal business. Retaining experienced lawyers is key for the successful future of the firm, while on the other hand, losing these valuable employees can be destructive in the form of direct and indirect costs. Moreover, there could be a fair chance that a competing firm attracts a well-trained professional. There is even a risk of losing clients to this other firm, if the relationship between the lawyer and client is strong. This is a serious problem for law firms and is something that keeps them awake at night. Within law firms, legal professionals learn the profession, procedures and behavior by intensive mentoring and a high level of on-the-job training. This personal accompaniment and guidance are done by a senior professional, with his or her own leadership style. This argument combined with literary findings that suggest that leadership style could be a possible predictor of turnover intentions, resulted in the selection of two relatively different leadership styles that were selected as forecaster in this study. The 
results of this study indicate that when empowering leadership is perceived by legal professionals, this has a direct effect on their turnover intentions.

The effect of leadership style measured on turnover intentions was significant for the construct of empowering leadership. Although the items to measure empowering leadership were validated items from previous research, the perception of empowering leadership by legal professionals was represented by two dimensions. The first factor of empowering leadership that was extracted from the data came from the items that were grouped in the research of Ahearne et al. (2005). This factor was abbreviated in this research as "PCA," which originated from the key words in the above groups "Participation, Confidence and Autonomy." The other factor, in this study named "M" in this study, was obtained from the items that are grouped under the phrase "meaningfulness of work." Both factors showed a strong coherence with each other, and a significant effect on turnover intentions was measured in the relationship of both dimensions. Within the context of this study, professionals are more likely to stay at the law firm if they observe empowering leadership. Furthermore, for both concepts the direct effect that was also hypothesized beforehand was correspondingly measured on the construct of the psychological contract breach. As expected, the perception of a psychological contract breach has a positive direct effect on lawyers' intend to leave the firm. In other words, if a legal professional has a high perception of psychological contract breach, this increases the chance of leaving the employing law firm. An important new aspect within the research done, was that there is not much known about the mediating effect of the assumptions, expectations and promises made about the job, the firm, and the relationship between employer and employee, between empowering leadership and voluntary employee turnover. This research indicates that the positive effect that the perception of empowering leadership has on turnover intentions of professionals, is also measured when mediated by the concept of psychological contract breach.

These findings show that empowering leadership significantly lowers the chance that a lawyer of (candidate) voluntarily decides to leave the employing firm. And that the relationship between turnover intentions and the parts of empowering leadership that can be expressed as the participation in decision making, expression of confidence in high performance, and providing autonomy from bureaucratic constraints, can be explained by the perception of a psychological contract breach. $\backslash$

This study also indicates that this is not the clarification for the second factor that was extracted from the empowering leadership construct. A possible explanation why the "meaningfulness of the work" is not mediated by a possible psychological contract breach might lie in the fact that a legal professional who executes its legal profession within a legal professional service firm is very aware of his or her contribution and meaningfulness to the law firm. To compare this with fast moving consumer goods; the lawyer itself is the "Coca Cola"-recipe. For a soda producing company this is the most valued asset in the company, likewise for legal professional service firms this is the knowledge of its lawyers. So, of course the legal professional will not doubt about the meaningfulness of the work that he or she provides to the law firm.

\section{Conclusions, Limitations and Future Research Directions}

After analysis of the data, the results indicate that empowering leadership is significantly related to psychological contract breach and also towards voluntary turnover intentions of the lawyer. Therefore, within the context of this study, there is a strong indication that when a high perception of empowering leadership style is measured in a law firm, this significantly lowers the chance that a lawyer, legal tax advisor or (candidate) civil law notary decides to leave the employing law firm.

The analysis furthermore reveals that in this research the construct of empowering leadership is composed in two dimensions. The first dimension that was extracted was measured with questions in the survey about the leaders' ability to foster participation in decision making, the expression of confidence in high performance, and providing autonomy from bureaucratic constraints. The results indicate that for this dimension, the relationship between empowering leadership and turnover intentions can be explained by the perception of a psychological contract breach (full mediation).

Legal professionals feel more committed to the firm when their perceptions and promises made between them and their leaders are kept. When a young professional is recruited and starts working at the 
firm, all kinds of expectations about the culture, colleagues, environment, knowledge transfer, opportunities, et cetera exist. These are often subjects that are not noted in a written contract, but are part of the whole experience of working for the firm. If every day work with all its facets does not match these unwritten expectations or promises made during the recruitment period, for example a "promise" made about the enormous knowledge transfer between colleagues, this leads to psychological contract breach and consequently to early turnover.

Although quantitative research is a good method to prove whether relationships between constructs exist, it proved to be very difficult to gather a large sample within the Dutch legal sector. This has probably to do with the fact that the preselected group of potential respondents was narrow. The number of qualified lawyers who work in a manager-subordinate type of relationship (e.g. law firms with at least 5 lawyers) is in the Netherlands probably not higher than $20 \%$ of the total number of qualified lawyers in the Netherlands, around 3500. Moreover, this shallow pond of respondents exists of lawyers who register all time spend during the day in order to be billable for the law firm. Another limitation of this research was that the data was only gathered among legal professionals. This raises the question if the results found in this study would differ if the population would include other professionals, for example consultants or accountants. Another recommendation for further research is to use a different technique in obtaining the data. Interviewing lawyers or (candidate) civil law notaries would have made it possible to anticipate more on the answers given and to find out more detailed information about the reasons behind the conceptual constructs and subsequently give more insight on the "why" of the relationships between the different constructs.

\section{REFERENCES}

Adler, P. S., \& Kwon, S. W. (2002). Social capital: Prospects for a new concept. Academy of Management Review, 27(1), 17-40.

Becker, G. (1964). Human capital: A theoretical and empirical analysis with special reference to education. New York: National Bureau of Economic Research.

Bontekoning, A. (2017). The power of generations: How to keep aging organizations up to date. Amazon Digital Services LLC.

Brace, N., Kemp, R., \& Snelgar, R. (2012). SPSS for psychologists (5th ed.). Psychology Press.

Carmeli, A., \& Weisberg, J. (2006). Exploring turnover intentions among three professional groups of employees. Human Resource Development International, 9(2), 191-206.

Clinton, M. E., \& Guest, D. E. (2014). Psychological contract breach and voluntary turnover: Testing a multiple mediation model. Journal of Occupational and Organizational Psychology, 87(1), 200207.

De Cuyper, N., Mauno, S., Kinnunen, U., \& Mäkikangas, A. (2011a). The role of job resources in the relation between perceived employability and turnover intention: A prospective two-sample study. Journal of Vocational Behavior, 78(2), 253-263.

De Cuyper, N., Van der Heijden, B. I. J. M., \& De Witte, H. (2011b). Associations between perceived employability, employee well-being, and its contribution to organizational success: A matter of psychological contracts? The International Journal of Human Resource Management, 22(7), $1486-1503$

Dess, G. G., \& Shaw, J. D. (2001). Voluntary turnover, social capital, and organizational performance. Academy of Management Review, 26(3), 446-456.

Glass, A., (2007). Understanding generational differences for competitive success. Industrial and Commercial Training, 39(2), 98-103.

Hakimi, N.A., van Knippenberg, D., \& Giessner, S. (2010). Leader empowering behaviour: The leader's perspective. British Journal of Management, 21(3), 701-716.

Hausknecht, J., Trevor, C., \& Howard, M. (2009). Unit-level voluntary turnover rates and customer service quality: Implications of group cohesiveness, newcomer concentration, and size. Journal of Applied Psychology, 94, 1068-1075. 
Hayes, A. F. (2014). PROCESS procedure for SPSS release 2.13.1. Retrieved from http://www.guilford.com/p/hayes3.

Holtom, B., Mitchell, T., Lee, T., \& Eberly, M. (2008). Turnover and retention research: A glance at the past, a closer review of the present, and a venture into the future. Academy of Management Annals, 2(1), 231-274.

Leana, C. R., \& Van Buren, H. J., III. (1999). Organizational social capital and employment practices. Academy of Management Review, 24(3), 538-555.

Liao, H., \& Subramony, M. (2008). Employee customer orientation in manufacturing organizations: Joint influences of customer proximity and the senior leadership team. Journal of Applied Psychology, 93(2), 317-328.

Liao, H., Toya, K., Lepak, D., \& Hong, Y. (2009). Do they see eye to eye? Management and employee perspectives of high-performance work systems and influence processes on service quality. Journal of Applied Psychology, 94(2), 373-391.

Lub, X. D., Blomme, R. J., \& Bal, P. M. (2011). Psychological contract and organizational citizenship behavior: A new deal for new generations? Advances in Hospitality and Leisure, 7, 109-130.

Lub, X. D., Nije Bijvank, M., Bal, P. M., Blomme, R. J. \& Schalk, R., (2012). Different or alike?: Exploring the psychological contract and commitment of different generations of hospitality workers. International Journal of Contemporary Hospitality Management, 24(4), 553-573.

Macky, K., Gardner, D., \& Forsyth, S., (2008). Generational differences at work: Introduction and overview. Journal of Managerial Psychology, 23(8), 857-861.

Morrow, P., \& McElroy, J. (2007). Efficiency as a mediator in turnover-organizational performance relations. Human Relations, 60(6), 827-849.

Pearce, C. L., Sims Jr., H. P., Cox, J. F., Ball, G., Schnell, E., Smith, K. A., \& Trevino, L. (2003). Transactors, transformers and beyond: A multi-method development of a theoretical typology of leadership. Journal of Management Development, 22(4), 273-307.

Redeker, M., de Vries, R. E., Rouckhout, D., Vermeren, P., \& de Fruyt, F. (2014). Integrating leadership: The leadership circumplex. European Journal of Work and Organizational Psychology, 23(3), 435-455.

Sawa, B., \& Swift, S. (2013). Developing high-performing organizations: Keys to recruiting, retaining, and developing people who make the difference. Leadership and Management in Engineering, 13(2), 96-100.

Shaw, J. D., Duffy, M., Johnson, J., \& Lockhart, D. (2005a). Turnover, social capital losses, and performance. Academy of Management Journal, 48(4), 594-606.

Shaw, J. D., Gupta, N., \& Delery, J. E. (2005b). Alternative conceptualizations of the relationship between voluntary turnover and organizational performance. Academy of Management Journal, 48(1), 50-68.

Staw, B. M. (1980). Rationality and justification in organizational life. In B. M. Staw \& L. Cummings (Eds.), Research in organizational behavior (Vol. 2, pp. 1-57). Greenwich, CT: JAI Press.

Subramony, M., \& Holtom, B. (2011a). Customer satisfaction as a mediator of the turnover-performance relationship. Working paper, Northern Illinois University, DeKalb.

Subramony, M., \& Holtom, B. (2011b). The long-term influence of service employee attrition on customer outcomes and profits in a relationship-based business. Working paper, Northern Illinois University, DeKalb.

Thomas, K. W., \& Velthouse, B. A. (1990). Cognitive elements of empowerment: An "interpretive" model of intrinsic task motivation. Academy of Management Review, 15(4), 666-681.

Van der Smissen, S., Schalk, R., \& Freese, C. (2013). Organizational change and the psychological contract: How change influences the perceived fulfillment of obligations. Journal of Organizational Change Management, 26(6), 1071-1090.

Waldman, D. A., Carter, M. Z., \& Hom, P. W. (2015). A multilevel investigation of leadership and turnover behavior. Journal of Management, 41(6), 1724-1744. 